\section{ENTRE A PAZ E A GUERRA}

\section{Oswaldo Aranha}

Antes de pronunciar a conferência abaixo publicada, o Sr. Oswaldo Aranha foi saudado pelo diretor da Faculdade, prof. José Salgado Martins, que lhe dirigiu esta oração:

" $A$ vossa presença, sr. embaixador OSW ALDO ARANHA, nesta Casa onde se ensina o Direito, assume marcante significação, na hora crucial que vive o mundo.

As vossas atitudes e a vossa palavra, imantadas de superior idealismo, constituem uma perene mensagem de paz $e$ de confiança na civilizaçäo e na cultura, como fôrças harmonizadoras dos conflitos humanos que amarguram a nossa época e explicam as dolorosas contradicốes do sua experiência política, econômica e social.

Entre essas fôrças superadoras das antíteses contemporâneas, está o Direito em cuja estrutura dinâmica todos os interêsses legítimos e todos os autênticos valores do espírito podem e devem abrigar-se à sombra da sanção reabilitadora.

O processo histórico da cultura, - disse-o um dos filósofos do nosso tempo, - é um processo essèncialmente espiritual. As suas fôrças propulsoras, por assim dizer, são constituidas por conteudos espirituais, por ideais, por valores. Mas tudo depende da natureza e da indole dêsses valores. $E$, por isso, no próprio processo de sua realização, surge o momento trágico da cultura, quando o dizer $\operatorname{sim}$ a certo valor importa necessàriamente no dizer não ao valor que lhe é oposto.

No campo do Direito, essa polaridade inerente ao mun-

do dos valores se manifesta com singular energia, porque a coerção da norma jurídica deve ser uma realidade ordenadora da vida para a realização do seu destino social, cujo escopo é o bem comum, e tudo que se opõe a êsse escopo deve ser renegado.

Valores religiosos, éticos, políticos, econômicos, estéticos, sociais, enfim, inspiram a tôda a estrutura jurídica, presidem ao seu ritmo, regulam o seu desenvolvimento e tornam-se consubstanciais ao seu dinamismo operante.

Instituindo um clima vitalizador onde êles possam afirmar-se vitoriosamente, a paz, a autêntica paz, cristã $e$ democrática, fruto de uma concepção integral do homem e ao mesmo tempo ordenação moral e jurídica, é o mais alto valor social, pedra angular da cultura, do progresso, do sonho de aperfeiçoamento que seduz a povos e nações.

Porque sois, sr. OSWALDO ARANHA, um dos apóstolos dessa paz autêntica, reconciliadora do homem com os seus destinos de ser espiritual e livre e com a sua condiçäo de criador de cultura e de valores, vós estais em vossa própria casa, semeando o próprio campo e colhendo na própria seara.

$N$ ão sois por outro lado um estranho ou um peregrino de fascinante ideal que nos visite $e$ nos fale pela primeira vez.

Os rio-grandenses vos conhecem, admiram e estimam como o paladino das melhores causas em que já se empenhou e ainda há de empenhar-se o patriciado moral do Rio Grande do Sul.

$V$ ós o dissestes em momento solene, quando a sociedade desta capital, sem distinções de classes e de côres partidárias, vos tributava homenagens excepcionais: "A minha vida é uma experiência gaúcha.. As constantes da minha origem natal dominaram tôda uma existência que tenho vivido entre os altos e baixos das mais responsáveis funções no país e no mundo, algumas delas já históricas."

Nessa fidelidade às origens reside uma das notas mais sedutoras da vossa eminente personalidade. Homem que assimilou o espirito do mundo, mercê de uma convivência com idéias e homens dos mais diferentes quadrantes do globo, não perdeu, no entanto, o sentido profundo da terra e da gente rio-grandenses, cujos impetos, fôrça e nobreza repontam no temperamento de um autêntico filho 
da campanha gaucha, cujas várzeas e coxilhas já sentiram - galope do seu flete ágil, na vertigem das califórnias ou dos entreveros, ou nas cargas de cavalaria da sua mocidade romântica e impetuosa.

Mesmo naqueles momentos de lutas fratricidas que punge ao coração recordar, Oswaldo Aranha se singularizava, não só pelo espírito de sacrifício que sublimava o heroísmo, mas pelo pensamento e pelo idealismo que presidiam a sua ação politica.

Naquele periodo de tão confinadas fronteiras partidárias, a sua personalidade já transcendia o seu partido e suscitava simpatias e aplausos nas outras correntes onde também se exercia a atividade cívica dos rio-grandenses. Porque sabe compreender e conciliar, o destino político de Oswaldo Aranha tem sido o de unir e fraternizar fôrças, idéias e criaturas que antes se situavam em antagonismos intransigentes.

Foi êsse insigne patriota quem mais contribuin pela inteligência e pelo coraçấo para promover a unidade politica do Rio Grande antes de Trinta, e talvez a sua vocacão de unificador possa ainda operar novos milagres cívicos, mercê de Deus e da nobreza e generosidade dos rio-grandenses.

Tão insignes as qualidades dêsse grande cidadão da América e do mundo que outros cenários e outros proble mas, desta vez com as dimensões do orbe civilizado, solicitaram a sua inteligência, cultura e operosidade, e a As sembléia das Nações Unidas o colocou, por duas vêzes, no pôsto mais alto da sua hierarquia política, na presidência do organismo internacional, conquistando assim Os waldo Aranha para o Brasil a glória mais pura que um pais livre pode aspirar: exercer através de seus grandes filhos uma sensivel ascendência moral nos destinos do mundo que nasce para a paz das convulsões recentes da guerra.

Ele que fôra, como chanceler do Brasil, durante o conflito mundial, o fiador do espírito democrático do nosso povo, tornou-se, no plenário das Nações Unidas, o expoente mais alto da consciencia democrática da América, na extraordinária tarefa de presidir a assembléia dos povos, contagiando-a com o élan do seu espírito criador.

Na orografia política do Brasil, Oswaldo Aranha é um dos cimos mais altos, donde se descortinam panoramas. ensolarados.
Ele é um exemplo de espírito público, de vocação tara as grandes causas do país e da humanidade, é a encarnação dos ideais de redenção do homem pela liberdade e pela cultura é uma floração de inteligência, no meio das urzes e dos espinhos que sinalam os rudes caminhos politicos do mundo.

A matéria-prima, com que trabalha em política, não se constitui dos episódios de corrilhos, das lutas de cam panário, do jôgo dós interêsses imediatos. São as grandes déias sadias e construtoras, o entusiasmo sagrado, a generosidade que redime, a compreensão que exalta, os ideais que libertam $e$ arremessam os homens $e$ os povos para os seus verdadeiros destinos.

Elle pertence à estirpe politica dos Nabucos e dos Ruys, dos Churchills e dos Roosevelts, dêsses titãs da arte e da ciência políticas, capazes de transfundir no espírito da nação a fôrça dos ideais que encarnam e capa zes de, com o exemplo e a palavra, arrastar as multidóes para os movimentos sísmicos da opiniāo que se perpetuam na história dos povos.

\section{Senhor OSWALDO ARANHA:}

Os títulos que conquistastes, d influência que o vosso pensamento e os vossos gestos exercem sôbre a opinião culta da América e do mundo, a experiência política que - vosso espirito acrisolou, assinalam para a vossa personalidade um lugar de relêvo impar entre os seus compatrícios.

A vossa presença nesta Casa é ainda a expressão da fidelidade às idéias matrizes da vossa vida e do vosso. apostolado militante.

Com a vocação para descobrir a unidade substancial e a identidade profunda entre os homens de uma mesma nação, entre as naçôes de um mesmo continente ou entre os continentes de um mesmo mundo, vós sempre operastes com o instrumento do Direito que é o sentimento do justo aplicado à soluçẫo dos dissídios sociais do homem.

Com efeito, a paz só será duradoura e fecunda quando encontrar na normatividade jurídica a protecaáo eficaz. àqueles valores consubstanciais, ao espirito do homem e à sua eminente dignidade como criatura de Deus e não como criatura do Estado, da raca ou da classe, ser mutilado e incompleto, simples animal político ou econômico. 
Por isso, será nas escolas onde se preleciona o Direito que os apóstolos da paz, como vós, poderão recrutar os legionários da sublime jornada. Só pelo profundo sen timento do Direito e pela extensão de uma consciência jurídica mais viva no mundo atual, poderemos salvar a humanidade, pela afirmação plena e pela defesa dos vam lores que darão sentido a um novo humanismo.

Sr. OSWALDO ARANHA:

Regressastes do interior do Rio Grande, depois de rever a vossa cidade natal, a histórica Alegrete, onde recolhestes, nas consagrações populares, a medida do afeto $e$ da admiração que mereceis daquele povo. Lá, naquele município fronteiro, pulsa ainda bem vivo o sentimento tradicional do Rio Grande e, a despeito de tôdas as injustiças do nosso tempo, o homem rio-grandense ainda se afirma com as características definidoras de um tipo singular, entre os outros grupos demográficos do Brasil.

$V$ ós sois um dos exemplares dêsse tipo magnífico de campeador generoso que tudo sacrifica pelo ideal $e$ pela fé na sua causa.

\section{Sr. OSWALDO ARANHA:}

Se ao Brasil já servistes em horas difíceis, prestandothe os mais assinalados benefícios, mais ainda êle espera do seu grande chanceler e do seu excelso embaixador, nos dias também dificeis em que retoma a experiêricia democrática e restitui novamente ao povo as prerrogativas de constituir o seu próprio govêrno.

Saudando o sr. Oswaldo Aranha e agradecendo-lhe a honra que concedeu a esta Faculdade, sei que o faço a um dos vultos mais insignes da minha pátria, credor do nosso afeto e da nossa admiração, portador dos títulos mais nobres a que um homem pode aspirar.

\section{ENTRE A PAZ E A GUERRA}

Esta não é uma conferência.

Entre o honroso convite para falar nesta tradicional Escola e êste momento, vivi, em minha terra natal, horas de tal emoção, que não me restou tempo nem mesmo tranqüilidade para pensar e menos ainda para escrever. E esta uma simples tentativa, desalinhavada e ditada, para, com a vossa cooperação, procurarmos juntos entender o mundo em que vivemos desentendidos homens e povos.

Não é também um discurso nem uma preleção. E um esbôço do meu próprio debate, íntimo e de consciência, a fim de permitir-nos, srs. professôres e acadêmicos, o exame de uma situação que é vossa, como é minha, porque estamos vivendo num mundo de cujo destino não nos poderemos separar.

A situação mundial é, pois, a realidade de que nos devemos ocupar. Proponho-me a expor minhas impressões como viajante que, após fazer a volta ao mundo, reduz a algumas considerações, linhas ou páginas, as regiões e as distâncias percorridas. Será uma conversa em tom familiar, a nossa, esta noite, sôbre a nossa família, que é, hoje, a família humana.

\section{CALENDÁRIO E GEOGRAFIA}

Começarei por dizer-vos que para boa compreensão da situação mundial precisaríamos rever nossos conhecimentos de História e de Geografia. Dividimos o tempo pelo calendário, mas nem por isso o tempo é divisível. Êle transcorre indiferente às nossas ficções. Nós o contamos por dias, semanas, meses e anos, e chegamos mesmo às medidas audaciosas das épocas, dos séculos e milênios. Tudo isso é uma ilusão, necessária e talvez prática, mas sem expressão real. A vida mesma nasce, transcorre e finda, sem se ater a essa regulamentação artificial a que ilusòriamente pretendemos sujeitá-la. A História é tempo, e, como tal, não é antiga nem medieval, e menos ainda moderna. É vida e, portanto, eternidade indivisível, que não se compadece nem com o aspecto efêmero de nossa existência nem com a ficção de nossas fórmulas.

O meu objetivo com essa digressão é apenas mostrar que, como a noção de tempo, o conhecimento da História e o da própria Geografia, tal como nos ensinaram, não ajuda, antes perturba a visão real do mundo e de seus problemas.

A Europa, por exemplo, é uma convenção. Não corresponde a uma realidade; é uma falsa idéia, adquirida como muitas outras que, infelizmente, presỉdem à interpretação da vida atual. $\mathrm{E}$, se houvesse dúvida sôbre a minha afirmação, perguntaria eu agora onde termina e mesmo onde começa a chamada Europa.

Falamos dela e articulamos todos os nossos raciocínios sôbre a base absolutamente errônea de uma unidade continental, de uma entidade mundial independente, mera criação nossa. A terra é uma só, mesmo porque os espaços terrestres, marítimos, e hoje os aéreos, se fundem no destino do homem como no dos povos.

A consciência da unidade geopolítica do mundo é a base mesma 
da nossa sobrevivência, pois estão certos os que atribuem à "ignorância da geografia mundial" os erros e crimes do século XX.

Mas, esta unidade não foi alcançada, e o predomínio da idéia fracionária, permitindo a cada povo uma concepção diversa da geografia de outro povo, como de regiões e de continentes, trouxe a confusão do nacionalismo, do isolacionismo e do próprio imperialismo, causa dos conflitos do nosso tempo.

E fora de dúvida, pois, que a estratégia polítiça democrática, especialmente a americana, moldou-se numa concepção geográfica errada, - como acentuou Weigert, - ao desprezar a lição de Bonaparte de que "a Geografia deve governar a política das nações".

Esta foi a razão pela qual um grande sociólogo do nosso tempo - Reves - afirmou que, vivendo na era de Copérnico, insistem os homens e os povos em raciocinar como Ptolomeu, segundo suas hipóteses e concepções.

As últimas guerras vieram confirmar não só a unidade política mundial como o êrro de procurármos dividir a Europa da Ásia e estas da África e da América, suas verdadeiras penínsulas.

"Sem descer à demonstração dessa afirmação, evidente por si mesma, basta-nos considerar que o "mapa esférico" veio revelar que o chamado oceano Ártico, para nós mais lendário que real, é um verdadeiro "Mediterrâneo polar" em tôrno do qual, talvez, a civilização travará a batalha do futuro. Ainda mais, o mapa, que era uma representação fixa de conhecimentos incompletos, puramente descritiva, é hoje, dentro da vida conjuntural dos povos, um elemento dinâmico, sugestivo, uma arma sem o uso da qual tôdas as armas e idéias podem falhar.

Não aventuro ao afirmar que a nação mais apta será aquela que possuir e conhecer os melhores mapas, mesmo porque da éscolha, no mapa, do lugar da futura batalha mundial, dependerá, estou certo, a sobrevivência da democracia, a nossa sobrevivência.

Uma nação, outrora, era considerada tanto mais civilizada quanto mais conhecia e trabalhava o próprio território e, hoje, será aquela que melhor ajustar a sua geografia física peculiar à geografia política mundial.

\section{O DESTINO DO BRASIL}

Estas considerações as fiz com o objetivo de realçar que só uma visão global, dentro da interdependência do "espaço-tempo" mundial, cada vez mais conjugado e reduzido, poderá nos permitir, ainda que de relance, a constatação da existência, no mundo e em nossa época, de uma subversão material, política e militar mundial capaz de inverter o processo histórico dos últimos tempos e influir, decisivamente, sôbre o destino do Brasil. O eixa mundial, afastando-se da chámada Europa, terá necessàriamente que se apoiar na Ásia ou na América, ou em ambas.

A nossa indagação deve, pois, cingir-se ao exame do curso atual \& futuro dos acontecimentos internacionais, a fim de podermos surpreender, se possível, o seu desenlace lógico e inevitável.

Ao fim da primeira Grande Guerra, a convicção era, baseada na concepção wilsoniana, de que se havia pôsto um fim às guerras. Não é esta agora a convicção mundial. A crença generalizada é que não se soube terminar a guerra nem se sabe quando vai recomeçar. A diferença dessas opiniões, se a isto se pode chamar opiniões diferentes, reside em que muitos acreditam na guerra imediata e poucos entendem que ela virá com o curso de alguns anos mais.

$\mathrm{Na}$ última guerra, a previsão não era difícil. Nesta, é quase impossível. Em junho de 1939, justamente porque minhas advertências não eram ouvidas e, após três meses de insistência, em reuniões ministeriais, no sentido de que deveríamos preparar o Brasil para uma guerra mundial a que seríamos arrastados, com, sem e até contra a nossa vontade, escrevi ao chefe do govêrno uma carta que consta do "Livro Verde do Brasil". Hoje, depois que vi confirmadas não só as minhas previsões em seus menores detalhes, quer quanto à guerra, seu curso e seu desfecho, quer quanta às suas repercussões internas em nossa vida, não posso, entretanto, falar-vos com a mesma segurança. Nada desejaria eu mais do que haver chegado a uma convicção para transmitir-vos nesta oportunidade, como fiz naquela aos então responsáveis pelos destinos brasileiros. Não creio, porém, que haja quem possa assegurar quanto tempo teremos dêste após-guerra ou se já estamos no período pré-bélico de um novo conflito mundial. Não sabemos mesmo se estamos em paz ou se, dados os choques existentes, a guerra atenuou-se para recobrar as fôrças de destruição necessárias a uma hecatombe ainda maior. Há os que pensam estarmos vivendo, apenas, o período indispensável à transformação, pelas grandes potências, dos armamentos usuais nos de destruição em massa. É o estágio de preparação, impôsto pelos novos processos e métodos, táticos e estratégicos, trazidos pelas novas armas, às velhas lutas entre os povos.

\section{A DECISÃO DO HOMEM}

Omar Bradley, Chefe do Estado-Maior americano, declarou que a paz e a guerra dependem do Politburo russo, pois terá que escolher 
entre uma e outra. Estamos vivendo dias angustiosos à espera dessa decisão. Não devemos, porém, perder a esperança. A verdade é que cada guerra reduz a possibilidade de novas guerras. Isto não significa a paz. Mas o fenômeno não pode deixar de pesar em nossas considerações. Os fatôres de uma guerra são complexos, quase infinitos. Mas o remate final é a decisão do homem. E esta terá que ajustar-se, mesmo a do Politburo, a uma realidade mundial que restringe, cada dia mais, a faculdade e a possibilidade de fazer e até de aceitar a guerra.

A guerra, em minha opinião, ainda que aparentemente paradoxal, acabará eliminada pela própria guerra. Se indejável ela tornar-se-á_impossível. Não desconheço nem obscureço as razões das guerras passadas e da continuação, na vida contemporânea, dos fatôres determinantes de tôdas as guerras.

A História, quase de nossa época, mostra como as nações que se prepararam para fazer a guerra, para ampliar o seu poderio, para implantar suas idéias, acabaram derrotadas, vencidas e arruinadas. Esta é a história de todos os tempos, a da Alemanha, em suas duas últimas guerras, a do Japão, a da Itália. Esta será a de quem se propuser substituí-las nesse plano de dominação mundial. Não é maịs possível na sociedade das nações, como na dos indivíduos, o predomínio exclusivo de um sôbre todos os demaïs. A civilização e a cultura são vontades em sí mesmas mais poderosas que as demais vontades. Os próprios governos, hoje, terão de vencer a necessidade de paz dos seus povos antes de promoverem a guerra, porque esta não destruirá sòmente a vida mas o futuro de vencidos e vencedores. Outrora, a guerra podia surgir e generalizar-se pelo assassinato de um príncipe, pela ambição de um "duce", ou pela loucura de um "fuehrer", como as duas últimas grandes guerras. Não é isso possível em nossos dias. Eisenhower disse que a guerra é uma coisa tão estúpida que pode surgir de uma estupidez, mas a verdade é que em nossos dias fatos mais graves, como substituições da estrutura de nações, conflitos como os da Grécia, da China, da Palestina, desagregações imperiais como as da Índia e da Birmânia, maiores que a da Sérvia em 1914 e a da Polônia em 1939, ao invés de provocarem a explosão de uma guerra mundial, associam e unem o mundo num esfôrço de conciliação e de paz.

\section{ESTADOS-UNIDOS E RÚSSIA}

As nações capazes de fazer guerras de caráter mundial reduziram-se apenas a duas: a Rússia e os Estados-Unidos. Antes, muitas outras, como a Alemanha, a França, a Polônia, a Itália, a Inglaterra,
- Japão podiam provocar um conflito mundial. Hoje, a guerra só será possível se os Estados-Unidos e a Rússia entrarem em conflito, dada a desproporção de elementos militares das demais e a sua imdada a desproporçáo de possibilidade de financiar nova guerra. O caso da Palestina, que revive a luta de raça e religião entre 250 milhões de muçulmanos e os incontáveis judeus, trouxe, justamente, não o choque, mas a reunião das duas grandes potências, cujo conflito se anuncia todos os dias das duas a possibilidade de em nossos jornais. Se quisermos, pois, examiná a possibilidade de uma guerra mundial, deveremos estudar a Rússia e os EstadosUnidos, nacões líderes do mundo atual, e analisar as probabilidades de um conflito entre êsses dois países. Só êsse conflito poderá trazer de um conflito entras, entre outros a conflagração geral. Năo vejo como outras causa antes dêste povos, possam provocar uma guerra mundial. Mas antes dêste exame, com o objetivo de trazer-vos ao assunto, parece-me necesexame, com o obtudiosos dos problemas internacionais chegamos neste após-guerra.

\section{O POTENCIAL CIVIL}

A primeira, como acentuou Eisenhower, é de que "a defesa a não cabe exclusivamente aos homens de uniforme", mas nacional não cabe exclusivamente do povo. A luta moderna não será decidida pelo país que, de início, tiver o maior exército, mas pelo

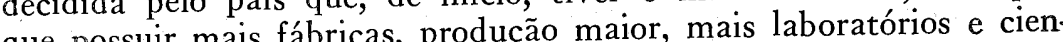
que posição política a capacidade econômica, a produção intistas. A posiça politica, a capacidade econimica, a prom dustrial, a aparelhagem tecnica, as reservas financeiras, enfim, o potencial civil, determinarão, em última instância, a posição militar.

Não vence mais uma guerra quem "chegar primeiro com o maior número", como queria Clausewitz, mas aquêle que tiver mais capacidade para produzir e empregar os novos elementos de destruicão criados pela tecnologia moderna. A futura guerra será mais industrial que militar, mais de máquinas que de soldados. Os geneindustrial que militar, mais de máquinas que nos altos comandos, terais, os almirantes e os brigadeiros, quando nos altos comandos, terão de ser "general managers ráticos e estragegistas. A demonstrasuperintendentes mais do crítico milição dêsse novo aspecto da tar, ao afirmar que "nunca erraram tanto os generais que ganharam a guerra e nunca acertaram tanto os que a perderam".

\section{ARSENAL DA DEMOCRACIA}

Os Estados-Unidos foram e terão de ser não só o "arsenal da democracia", a "fábrica da vitória", como a base de suprimento e mesmo de operações em uma guerra futura. Creio que, em caso de 
conflito mundial, o grande Estado-Maior das fôrças ocidentais ficará em Washington e o das outras fôrças provàvelmente em Moscou, mesmo porque o supremo comando não poderá mais ficar no campo da luta, montado em cavalos, como no tempo de Napoleão, ou em aeroplanos e "jeeps", como na invasão da Äfrica.

\section{A MELHOR DEFESA}

A ofensiva sempre foi e continua a ser a melhor defesa. Os últimos armamentos transformaram, com sua revolução técnica, a natureza da guerra, sem atingir seus princípios fundamentais. Essa transformação está em sua primeira etapa, mas mostra até onde poderá alcançar. As novas armas excedem, em alcance, velocidade. e poder, todos os nossos cálculos, e os laboratórios preparam instrumentos ainda mais surpreendentes, como bombas atômicas, projéteis transoceânicos, nuvens radioativas, "Tabun", chuvas mortíferas, aeroplanos, canhões, submarinos e projéteis com poder de destruição sem precedentes.

\section{A GUERRA TOTAL}

O futuro conflito terá, pois, de ser total e global. Será a luta de todos os povos e de tôdas as criaturas, em tôdas as terras, mares e céus. O trabalhador terá de ser mobilizado como soldado, bem como todos os homens, e até tôdas as mulheres, na medida de suas possibilidades. Nenhum esfôrco será inútil, esquêles que de suas derem concorrer para a luta, ou a pudút e aqueles que não pueliminados. A futura guerra inclú corpo, o pírito a máquina, tudo na sua trágica entrosagem o corpo, o espírito, a máquina, tudo que existe em cada país, para que algo possa, ao fim, sobreviver. Não será como as passadas, porque terá de ser decisiva e definitiva para o destino da Humanidade.

\section{A ESTRATEGIA GLOBAL}

A futura guerra exigirá não só a preparação militar, mas a nacional e a mundial, porque ela não irá decidir do predomínio de um povo sôbre outro, mas da vida futura de todos os povos. O mundo ja e ou será em breve tempo, do ponto de vista da estratégia, um só, porque a concepção fracionária, nacional pela estratégia global. A vitória sôbre muitas, como na última guerra, não será a vitória final. Esta será alcançada no terreno, sem dúvida, mas a vitória caberá aos que, no tempo, tiveram maior capacidade de multiplicação da aparelhagem da paz para destruir a da guerra.

\section{FÚRIA DESTRUIDORA}

Um outro aspecto que devemos ter presente é o da realidade de nossa época, tão bem definida pelo General Fuller, no seu famoso livro "Armaments and History": "Do nosso primeiro eixo à nossa primeira âncora surgiu o monstro Frankenstein - o período de trabalho do homem para sua própria destruição, da sua cultura, da sua civilização, do seu passado, do seu presente e do seu futuro". A revolução industrial, a desigualdade econômica crescente entre as populações humanas, o surto de superestados, a batalha ideológica, a insegurança moral, a irreligiosidade e muitos outros conflitos e fatôres do nosso tempo, concorrem para essa fúria de destruição caracterizada pelo esfôrço científico de descobrir novos meios para aniquilar tôdas as demais conquistas pacíficas dos séculos.

O mundo, na descrença de si mesmo, parece acreditar ùnicamente na sobrevivência daqueles que, com mais técnica e perícia, souberem e puderem destruir os outros.

$\mathrm{Nada}$, pois, nos deve preocupar mais, a fim de podermos bem concluir, do que conhecer a capacidade e o limite das novas armas, a possibilidade das novas invenções e de sua aplicação na ruína ou na proteção de nossos destinos.

\section{A ESPADA, O ESPÍRITO E A TÉCNICA}

A luta futura, se vier, será total, e a guerra, de três dimensões e mundial, será vencida por aquêle que melhor souber reunir, integrar e empregar, ao mesmo tempo, com o mesmo objetivo, mas em maior número de alvos, o maior número de armas, o maior potencial de fogo e o maior poder de destruição. A maneira de encarar uma guerra futura deverá fundar-se não só nos novos aspectos de um conflito, criados por essas surpreendentes aquisições da ciência, da técnica e da arte militar, mas igualmente naquelas fôrças da inteligência, da vontade, da economia e da política que até os nossos dias dominaram e presidiram à civilização e à cultura humanas.

O futuro será uma resultante da mạior ou menor consciência nossa das realidades por nós mesmos criadas. A guerra é obra do homem, e a paz também precisa ser obra do homem. $O$ homem melhora todos os dias e as dificuldades da vida humana provêm sobremodo do homem a quem se nega liberdade para melhorar.

A meu ver, a guérra não é mais possível como a fizeram os nosșos antepassados e nem mesmo os nossos contemporâneos. 
Napoleão afirmava que só havia dois poderes no mundo: a espada e o espírito, e, acrescentava, nas lutas duradouras o espírito acaba derrotando a espada. Mas hoje temos a técnica, que é espada e espirito. Ela decidirá das guerras e afinal acabará por tornar a guerra mundial impossível. Mas até chegarmos à eliminacão a guerra pela guerra, a paz não será a dos nossos à eliminação da pela qual morreram e morrerão aind muitos aquela Novas formas de luta surgirão na

As nacões sem

As nações sem indústrias, sem capacidade para fazer descobertas por falta de aparelhagem técnica ou de reservas para adquiri-las, como o Brasil, não poderão arriscar-se a provocar soluções bélicas para os seus problemas.

\section{A CONSTÂNCIA DAS GUERRAS}

A decisão de fazer a guerra, na quase totalidade dos povos, está, hoje, reduzida pela impossibilidade de enfrentar seu custo, sua des-
truição e suas sanções inevitáveis. truição e suas sanções inevitáveis.

A Humanidade, porém, não cessará de lutar e, ainda que custosa e aniquiladora, a guerra continuará, porque a violência não desertou de todo do coração humano.

Devemos, pois, encarar a situação mundial como uma resultante dos mesmos fatôres históricos e dos mais que acrescemos e acresceremos, muitos dêles capazes de modificar o curso dos acontecimentos humanos.

\section{A VITÓRIA DA PAZ}

À luz dessas idéias devemos, agora, encarar a hípótese de uma nova conflagração. A impressão geral, a que recolho todos os dias e a que leio em todos os jornais, é a de que estamos na iminência de uma guerra entre a Rússia e os Estados-Unidos. A "Batalha dos Súrbios", que se trava em Berlim, é apenas, segundo êsse ciário, o início da hecatombe mundial. Esta é a sensação de cada um e de todos nós, nos dias que estamos vivendo homens e povos. nha fé pacifista, atemorizado, abalado mais do que nunca na miprudência ocidental perturbar-se esmo, pela possibilidade de ver a tal, não descri de todo da vitória da

\section{As razões desta minha forma de pensar,}

rem da minha experiência forma de pensar, sem desesperar, decorPaz. Dar-vos-ei, o mais resumidamente problemas da Guerra e da considerações, que eu mesmo me faço, para não descrer de todo de uma solução pacífica para o conflito de nossos dias.

\section{FUNDAMENTOS POLITICOS E LEGAIS DA UNIDADE AMERICANA}

Os Estados-Unidos são nossos conhecidos, e a Rússia, sempre misteriosa, começa a revelar-se no mundo não só como ela é, mas como ela quer que venhamos a ser. O Departamento de Estado, intérprete da política norte-americana, acaba de fazer ao mundo. a seguinte đeclaração: "Os Estados-Unidos não estão em luta com a Rússia, mesmo porque as dúvidas existentes entre as duas nações não decorrem de conflitos exclusivos de ambas, mas de problemas mundiais". Esta afirmação é de importância capital e vem, mais do que quaisquer outras anteriores, contribuir para as nossas conclusões. Os Estados-Unidos excluem, assim, a possibilidade de conflitos diretos, para só admitirem soluções mundiais, e estas através dos órgãos internacionais existentes, ou sejam o Conselho de Ministros, as Comissões Mistas, a O.N.U., e, agora, o Pacto do Atlântico.

A atitude americana é lógica e obedece a razões profundas da forma de ver e encarar os problemas internacionais do povo norteamericano. Os Estados-Unidos são um conjunto de povos, quase de todos os povos, de tôdas as raças e religiões, cuja unidade assenta quase exclusivamente na sua Constituição. O "Bill of Rights" explica o milagre americano, a coesão do seu povo, a fôrça da sua iniciativa, o poder de suas oportunidades.

Não é uma nação orgânica como a Inglaterra, a Alemanha, a França, a Itália e outras, cuja existência continuará através de quaisquer mutações políticas e vicissitudes. A nação americana é uma criação própria, avançada sôbre os quadros de nossos tempos. Sua unidade decorre de fatôres geográficos, como todos, do seu progresso material e do seu bem-estar, mas os elos profundos da unidade americana não são pròpriamente raciais, nem os religiosos, nem os históricos, mas os políticos e legais. Existe, hoje, o povo americano, um grande povo, quase direi sem igual. Mas o fator de coesão, a fôrça da igualdade, a coerência de atitudes, a diretriz de orientação, a unidade americana, advêm não de uma raça ou de uma religião, ou de uma origem comum, mas da lei, da fidelidade aos princípios, da devoção ao regime, dos laços que a vida democrática criaram na comunidade americana.

\section{CONCEITO DE DEFESA NACIONAL}

Não tenhamos, pois dúvida de què, sem agressão direta, os Estados-Unidos não irão à guerra contra qualquer outro país, seja 
mesmo a Rússia. Mas, direis, a agressão, no mundo de hoje, não é ùnicamente aquela feita ao território de uma nação, mas qualquer ação em outra parte da terra que possa não só ameaçar a sua segurança e existência territoriais, como a integridade da sua forma de ser e de viver.

Terá de ser revisto, na vida dos povos, o conceito de defesa nacional. Esta já não repousa na inviolabilidade de uma fronteira, mas na consciência política e moral das nações.

Mas enquanto não se fizer essa revisão, ninguém definiu melhor a atitude americana do que Eisenhower em seu relatório final, apresentado a 7 de fevereiro dêste ano ao seu govêrno: "Nunca procuraremos a nossa segurança pelo domínio mundial ou pela conquista, em caráter preventivo, de uma nação que supomos estar-se preparando para nos atacar."

\section{O MISTERTIO RUSSO E O COMUNISMO}

A Rússia é uma nação bem diferente de tôdas, das velhas como das novas, mas sempre igual. A sua formação, a sua estrutura, a sua existência, não as podemos bem compreender. Hitler, em um dos seus mais dramáticos discursos, foi forçado a declarar, em plena guerra, com seus exércitos às portas de Moscou, de Leninegrado e de Stalingrado, que "cada passo na Rússia era um novo mistério". O comunismo, porém, veio, a meu ver, desvendar a Rússia: ela está resolvida não só a criar uma ordem comunista como a torná-la mundial. É verdade que na Rússia, ao que se afirma, não há comunismo, mas comunistas. Êstes, porém, a dominam e decidem de sua sorte, ameaçando a nossa. E êstes, nós os conhecemos. Lenine, pai da União Soviética, afirmou sempre que, sem vencer sucessivas e cada vez maiores guerras capitalistas, o comunismo não se poderia expandir e implantar no mundo. Trotsky sustentava não ser possível a existência de um estado socialista em um mundo capitalista, mas Stalin, revidando o Leninismo, defendeu e tornou vencedora a idéia da criação de um estado comunista bastante forte, capaz de resistir às agressões capitalistas e, por fim, vencê-las e dominar o mundo. E a Rússia do após-guerra, numa posição sem precedentes.

O conflito encontrou-a aliada da Alemanha e, agredida por Hitler, recebeu ela a ajuda das Nações Unidas. Não foi a guerra capitalista, como anunciaram seus profetas, mas a ajuda e a cooperação capitalista que a levaram à vitória. Mas ela não acreditou na sinceridade do nosso auxílio e, apenas vitoriosa sôbre a Alemanha, dobrou o número de povos sob o seu contrôle, estendeu em profundidade as fronteiras de sua segurança, alargou no mundo a penetra- cão de suas doutrinas e, com a chamada Europa quase completamente ocupada, Stalin exortóu seus povos, no discurso de 9 de fevereiro de 1946, como fazia Lenine, "a se prepararem, mais do que nunca, para as guerras inevitáveis enquanto o regime capitalista não desaparecesse da face da terra."

A Rússia, pois, não é mais um enigma, e devemos mesmo agradecer a franqueza dos seus líderes pelas suas advertências e pelas decer a franquezáricas do seu pensamento e das suas intenções.

\section{O DILEMA MUNDIAL}

Estamos, assim, meus Senhores, diante de duas grandes potências, uma que considera a guerra como fatal e inevitável e a outra que, no seu horror à guerra, não encontra ainda fôrças bastantes para organizar a Paz.

Êste é o dilema mundial: uma nação que acredita na guerra, e ainda não a pode fazer, e outra, a que quer a paz, e não a consegue manter.

Em outros têrmos, a nossa é uma era de indecisão entre a guerMas a Humanidade não pode viver na indecisão. Uma ra e a paz. Séá resultante terá de surgir dessa aparente dar resposta à trágica expectativa em que vivemos, homens e povos.

\section{A TAREFA DAS NAÇÕES UNIDAS}

Entre os que acreditam ser a guerra necessária e inevitável e os que pretendem pôr um fim às guerras, isto é, entre a Rússia, com que pretendem por Estados-Unidos, com seus aliados, medeia, imseus satelites, e os nossos dias com suas pedindo uma ou outra soluçãa, a reus imperativos.

A missão de nossa época é convencer os estados agressores, sejam capitalistas ou socialistas, de que quem escolher a guerra fará com o risco de sua própria destruição e de que a escolha da paz não traz riscos futuros. Esta é cada vez mais a tarefa das $\mathrm{Na}$ ções Unidas.

\section{ETERNA RENOVAÇÃO}

Na última guerra, ao invés do que sucede em tôdas as guerras, a derrota das armas inimigas não trouxe a das suas idéias. A "Estranha Alianca", como a chamou o General John Dane, em obra notável, fêz com que, não obstante a derrota das armas alemãs, 
italianas e japonêsas, acabassem encorajadas e prestigiadas as idéias totalitárias, contra as quais se haviam batido as democracias ocidentais. Êste inesperado desfecho veio, pois, transferir para um plano mais vasto e mais complexo, a solução do profundo conflito ideológico dos povos.

A realidade atual mostra uma grande superioridade, sob muitos aspectos, da Rússia sôbre nossa posição atual. Essa superioridade não é só militar, não é só material, mas política. Foi ela granjeada com os nossos erros, mas poderá crescer se insistirmos em errar. Representamos uma velha ordem que se quer manter "à outrance" contra uma nova ordem que se quer impor. O mundo porém é uma eterna renovação. A Humanidade é uma ininterrupta ânsia de aperféiçoamento. A inquietação humana, em procura de novas aquisições, é a característica do homem. A Rússia é um aceno a essa condição. Os povos, derrotados ou vencedores, não terminaram a luta satisfeitos. Uma expectativa domina a consciência mundial. Os povos europeus, cansados, esgotados, empobrecidos, não crêem: mais no passado e nós não lhes acenamos com um futuro melhor. Insistimos, como ainda recentemente anotou Laski em relação a um discurso de Churchill, em fórmulas revogadas pela experiência e pelas provações.

Não podemos, pois, negar que a consciência do homem ocidental está vaciliante entre a nossa ordem e uma outra qualquer, desde que não seja a nossa. Uma nova concepção, capaz de conciliar os extremos atuais, terá que surgir, como em outras épocas. Nosso problema não é reorganizar o passado. A consciência do homem que sofreu duas guerras, sobremodo na Europa e na Ásia, é hoje uma terra de ninguém à espera da primeira sugestão, da primeira esperança, do primeiro dominador. Esta é, indiscutidamente, a noss maior fraqueza e a razão da insegurança em que vivemos em relação a nós mesmos.

\section{CONFRONTO DE FÔRÇAS}

A fôrça da Rússia assenta no divisionismo democrático, fraqueza inerente ao nosso sistema econômico e político. ế fora de dúvida que ela tem o maior exército mundial em pé de guerra, o maior nümero de aeroplanos, uma unidade absoluta de comando, que é uma fôrça poderosa na ação, que suas reservas humanas e de matériasprimas são quase inesgotáveis. É, igualmente, fora de dúvida que ela conta, sob seu contrôle, com tôdas as organizações comunistas espalhadas na terra, vanguardas disciplinadas e perigosas, capazes de entravar e sabotar a ação das nações democráticas. E fora de dévida, ainda, que, no mapa da Europa, a sua vontade podia traçar divida, ainda, que, não só de sua influência, como de sua dominação. a Pode-se, mesmo, afirmar que, como Berlim, a Europa está à sua mercê.

A recomposição das nações ocidentais, econômica, política e militarmente, é uma das maneiras de deter a Rússia sem recorrer à guerra.

A Alemanha, a parte maior e melhor, está com o ocidente, em proporções grandemente favoráveis.

A economia européia e a russa, com seus satélites, mostra não haver um desequilíbrio, salvo em produção agrícola, capaz de comprometer desfavoràvelmente uma ação próxima, um desenlace ou prometer desfavoravelmente existentes serão corrigidas e mesmo um conflito. As desvantagens existentes serão corrigidas e mesmo superadas pelo plano Marshall e pelo Pacto do Atlântico. As populações são loúcicidade, de química e muitas outras das nações ocicarvão,

A recuperação ocidental, com o auxílio americano, será acelerada e efetiva, ao passo que a russa, mesmo com a execução do novo plano qüinqüenal, demandará mais de um decênio de trabalho' e de esforços. $\mathrm{Na}$ carreira da recuperação, as nações ocidentais voltarão ável anterior à guerra, senão igual, aproximado, antes da táno A produção soviética decresceu em todos os setores e ainda não voltou a aproximar-se dos índices básicos nem em aço, nem em carvão, nem em petróleo e nem mesmo em trigo e outros cereais. O trabalho russo é de pouco rendimento e deficiente a organização econômica do país. $O$ seu sistema de transporte não pode ser mais precário. Sua produção industrial atual corresponde à dos Estados-Unidos em 1905 e, acreditando-se em seus planos e projetos, chegará, em 1960, à do povo americano em 1913. Sua produção agrícola é grande, a maior da Europa e Ásia, mas muito inferior, em quálquer produto, à dos Estados-Unidos e, em quase inferior, em qualquer produto, à dos Estados-Unidos e, em quase todos os ítens, inferior às necessidades de sua população. E, econômicamente, uma nação do século XIX. Os seus satélites, salvo em poucos produtos industriais, e alguns extrativos, não a poderão ajudar. Eles representam um pesado encargo econômico, político e, mesmo, militar.

A fôrça da Rússia é o "Exército Vermelho", a sua posição estratégica no coração da terra, as suas reservas humanas e de matérias-primas, a unidade política e militar e a expansão de suas idéias revolucionárias. E u'a massa humana em pé de guerra, dispondo ao todo de 76 divisões nas zonas de ocupação e mais 75 divisōes dos países satélites, que alcançam, juntamente com as fôrças 
metropolitanas, mais de 5 milhões de soldados em armas. Sua fôrça aérea é de 30 mil aeroplanos dos quais quase a metade em serviço ativo. Sua armada, que Molotoff, em famoso discurso, prometia desenvolver até igualar as maiores do mundo, não tem, ainda uma fôrça capaz de influir nos oceanos e mesmo nos mares.

A Rússia tem, pois, na balança dos poderes, em seu favor: 1) a unidade estratégica de Moscou; 2) a posição privilegiada de ocupação e de predomínio continental, no ocidente e no oriente; 3) confusão das nações ocidentais; 4) a manutenção em pé de guerra de fôrças militares muitíssimo superiores às demais; 5) a organizáção comunista em todos os países; 6) as reservas humanas próprias e as dos países satélites; 7) a expectativa de uma crise econômica e financeira dos países capitalistas.

Estas șão, em resumo, as forças da guerra, contra as quais de-vemos alinhar as da Paz, sem mesmo cogitar da que são muitas e as de seus satélites, que ela não poderá jamais suprir. Entre elas, a meu ver a maior, que compensa e excede a da indecisão e da angústia ocidentais, é a que decorre da oposição comunista à natureza humana, à forma de ser e de viver do homem, mesmo do russo que, mais dia menos dia, acabará, como o hindu, a birmanês, o japonês e tôda a criatura, por compreender que a liberdade e a dignidade são bens inestimáveis.

Mas não devemos assentar nosso futuro na incerteza ou insegurança alheias, mas em nossa própria capacidade e energias.

\section{AS FÔRÇAS DA LIBERDADE}

Verificamos, ainda que em linhas apressadas, as fôrçaś e fraquezas russas e, agora, devemos estudar as das nações democráticas.

Foi Theodoro Roosevelt quem afirmou, com espírito profético, que, se a democracia não tivesse condiçôes próprias para vencer as fôrças do despotismo e da autocracia, não teria nem surgido nem se mantido contra elas nas terras livres das Américas e muito menos se alargado a tôdas as terras e a tôdas as consciências. A última guerra, colhendo de surprêsa e desarmadas as nações democráticas, foi a demonstração final da impossibilidade de serem vencidos os povos livres. A liberdade é a maior fôrça já criada e a única capaz de multiplicar as demais fâras materiais ena Eisenhower, o comandante da vitória definiu com sabedoria o poder da liberdade." "O nosso futuro, disse ele, éá "O nosso futuro, disse êle, não será alcançado pela fôrça. A segurança de um país não pode ser medida pelas reservas e estoques de munições, pelo número de homens em armas ou pelo monopólio de armas invencíveis. Esta era a idéia de poder da Alemanha e do Japão, que a experiência da guerra mostrou ser falsa. Mesmo na paz os índices da fôrça militar não merecem confiança porque as armas se tornam obsoletas. Grandes exércitos decaem após sacrificar o país para os manter, e o monopólio dos engenhos é sempre transitório. Mas as reservas espirituais da nossa cultura e da nossa civilização, aplicadas com prudência e sabedoria, à solução dos problemas diários, estas, sim, são invencíveis e acabarão por superar tôdas as aflições contemporâneas."

Podemos, pois, confiar em que, sejam quais forem os perigos e ameaças à paz e sejam quais forem os êxitos iniciais de uma agressão, as fôrças da liberdade acabarão vitoriosas.

\section{O CAMINHO DA PAZ}

A última guerra não encerrou seu ciclo e nem está encerrado o ciclo das guerras. O caminho da Paz, porém, pode ser simples e, talvez, mais fácil do que o da guerra, dependendo, apenas, de como nos conduzirmos. A última guerra veio reacender a luta ideológica, a religiosa e até a racial. As alterações na velha balança de poderes, que governava o mundo, trouxeram a ânsia de libertação das regiões coloniais entreabrindo uma nova era de independência para os povos secularmente escravos ou dominados. A Humanidade, como uma grande família após uma desgraça enorme, procura desesperadamente partilhár a herança do próprio destino. Êste não poderá ser o da destruição total. Não podemos acreditar que estejamos vivendo num mundo suicida. Seria admitir não só que perdemos a noção mesma da vida, como o instinto de conservação. Todos os debates e conflitos humanos, no fundo, decorrem de uma diferente concepção da vida entre as criaturas e os povos, grandes e pequenos.

Nós, os ocidentais, representamos uma forma de pensar, de trabalhar, de crer e de viver. Tudo, entre nós, é aquisição da convivência e da cordialidade. É compreensão da solidariedade e obra da tolerância. Sem êsse fundo moral não seriam possíveis a civilização e a cultura ocidentais. Acreditamos raquilo que nos fêz grandes, fortes e bons e esperamos que a rãão humana reconduza os povos a êsse caminho. A democracia, para nós, é uma consequiência da nossa forma de ser. Não é uma concepção política em si mesma, mas a maneira mais digna de viver e até de sobreviver. A agressão é, para nós, um crime, que o indivíduo não deve praticar e ainda menos os povos. E um ato condenado pela repulsa da nossa consciência.

Não são assim, porém, todos os povos. Em outras regiões da terra reina ainda o preconceito racial, o religioso, o político e a violência é considerada como base da vida. A lei é a do mais for- 
te e até do mais crúel. A necessidade não conhece limites e a expansão não tem fronteiras. A vida é uma luta exclusiva de interêsses materiais e os aspectos morais não contam nas suas deliberações. Chegam mesmo a afirmar que a família, a virtude, a honra, a fé e a liberdade são meros preconceitos.

As nações democráticas, em caso de um conflito mundial, lideradas pela América, têm a vitória das armas assegurada por forma iniludível. Mas uma nova guerras ruína total dos vencidos e a econômica, política e moral dos vitoriosos. A civilização e a cultura, as obras-primas do homem, serão soterradas nessas ruínas.

A O.N.U. foi criada para manter a $\mathrm{Paz}$ pela fôrça das nossas idéias. Ela surgiu na guerra e da guerra, mas inspirada na $\mathrm{Paz}$. uma expressão do nosso idealismo. Como tôda ou na padece das condições de sua época. Mas é destinada a sobreviver. A sua infância será difícil num mundo doente, física e moralmente. Mas o nosso dever, como acentuou Eisenhower, o líder militar da vitória, é ampará-la por tôdas as formas a fim de que militar da tância suprema, possa resolver pacificamente o conflito mundial.

Não podemos excluir de todo tão trágica possibilidade, uma vez que a Rússia poderá, ante a crescente organização democráticas, com o fim de deter pacifica organização das naçõe precipitar o mundo na guerra.

\section{ANTAGONISMO ENTRE DOIS MUNDOS}

A situação política mundial, hoje, é determinada aparentemente pelo antagonismo entre dois mundos, colocados em dois pólos opostos pelos seus sistemas econômicos, políticos e sociais. O grande drama da nossa época vem, porém, do fato de 1 bilião e $500 \mathrm{mi}$ Ihões de criaturas, quase $2 / 3$ da população mundial, na Ásia mibém na Europa, estarem, após púltima na Asia e tamnova forma de viver, ou melhor, de sobreviver. Estamos assistindo ao mais extenso e mais radical período de transformação do maior número de povos em tôda a história da Humanidade. A China India, a Birmânia e a Indonésia, com quase um bilião de criaturas,
são indicações dramáticas.

Direi, mesmo, que a terra tôda está sacudida por um movimento sísmico da necessidade e da consciência dos povos. Sentimos todos que das ruínas da guerra uma nova ordem quer erguer-se com novos materiais e idéias novas. No fundo de todos os incidentes internacionais, na O.N.U., em Berlim, na Coréia, na Grécia, em Moscou, em Washington, podemos surpreender que a luta se trava

entre os que querem manter o "statu quo" e os que o querem mudar. As fôrças que apóiam essas duas atitudes são imensas, as materiais e as morais. Mas, a meu ver, não são irreconciliáveis. A Rússia e os Estados-Unidos lideram essas duas tendências e, já hoje, acredito, começam a compreender que existe uma solução capaz Ale conciliá-las.

\section{ENTRE A PAZ E A GUERRA}

Entre a paz e a guerra processa-se a maior transformação das massas humanas. A Rússia apóia a nova ordem revolucionária e os Estados-Unidos defendem a ordem democrática existente. Não há, como se supõe, uma luta entre essas duas grandes nações, capaz de arrastar as demais. O drama é de todo o mundo e de todos os povos. Mas o mundo terá que melhorar. Êle veio melhorando até nós, arrancando das eras de barbárie, e não poderá parar e ainda menos retroceder. As dificuldades são grandes, mas muito maiores foram as vencidas pelos nossos antepassados. Assim como crescemos da era colonial, todos poderão crescer. E todos estão crescendo em cultura e civilização. As resistências de alguns são grandes e até violentas, tornando-os quase inacessíveis aos benefícios de nossos acenos e propósitos. Já foram, porém, maiores. A inteligência humana não conheceu ainda dificuldades insuperáveis. A História é uma renovada vitória da inteligência. Não devemos, pois, ser pessimistas e menos, ante essas incompreensões, renunciar à tarefa histórica da civilização e da cultura ocidentais. A resistência e a agressividade de outros povos não serão jamais capazes de superar a inspiração, arrefecer a determinação e trazer a desunião das nações democráticas.

A coalizão está feita na O.N.U. para propiciar e favorecer, pela evolução, as grandes transformações econômicas, políticas e sociais da nossa época, e para evitar e mesmo tornar o recurso à violência e à guerra cada vez mais difícil, senão impossível.

Nenhum povo, ou reunião de povos, poderá, em minha opinião, se prestigiarmos a obra da O.N.U., evitar a vitória pacífica dá Paz. 